\title{
MAQĀṢID ASY-SYARI'AH PENGERTIAN DAN PENERAPAN DALAM EKONOMI ISLAM
}

\author{
AMINAH \\ Mahasiswi Pasca Sarjana UIN Sumatera Utara Jurusan Ekonomi Syariah
}

\begin{abstract}
Basically syariah includes a broadly discussion, because besides talking about the interaction with Allah (ibadah), it is also with another human (muamalah). The focus of muamalah is to manage the Muslims life in their interaction with others, include the vital thing, economic side. Economic issues closely related to the benefits; because it is very important in Islamic economy and occupy a very central issues to judge. The growing era developed with every different innovations of life, appearing new events untapped by classical fiqh. On the other side, with the varieties of benefits come, we must be careful with the benefits that will be reached.
\end{abstract}

Keywords: Maqāșid Asy-Syarī'Ah, Application, Islamic Economy

\begin{abstract}
Abstrak
Sejatinya syariah mencakup pembahasan yang sangat luas, karena selain menyentuh interaksi hamba dengan Tuhannya (ibadah) juga interaksinya dengan sesama (muamalah). Fokus dari muamalah adalah mengatur kehidupan Muslim dalam interaksinya dengan sesama makhluk lainnya termasuk bagian yang sangat vital yaitu ekonomi. Masalah ekonomi erat kaitannya dengan kemaslahatan. Karena mașlahah sangat penting dalam ekonomi Islam dan menduduki tempat yang sangat sentral dalam menentukan hukum. Zaman yang terus berkembang dengan berbagai inovasi kehidupan, muncul kejadian-kejadian baru yang belum tersentuh fikih klasik. Di sisi lain bahwa cakupan, kriteria dan ragaman mașlahah yang bervariasi menuntut kita untuk lebih teliti di dalam menentukan sesuai dengan Mașlahah yang paling utama untuk dicapai.
\end{abstract}

Kata Kunci: Maqāṣid Asy-Syarī`Ah, Penerapan, Ekonomi Islam

\section{PENDAHULUAN}

Dalam Islam ada tiga rangkaian penting dan menjadi satu keutuhan dalam membentuk pribadi muslim yang sempurna yaitu akidah, syariah dan akhlak. Ketiga hal tersebut menjadi satu kesatuan yang tidak dapat dipisahkan satu sama lain. Setiap muslim wajib mengetahui dan mengamalkan dalam kehidupan sehari-hari. Dari ketiga unsur tersebut syariah merupakan 
FITR AH Jurnal Kajian Ilmu-ilmu Keislaman

Vol. 03 No. 1 Juli 2017

pembahasan yang sangat luas, karena selain menyentuh interaksi hamba dengan Tuhannya (ibadah) juga menyentuh interaksi hamba dengan sesamanya (muamalah). Fokus dari muamalah adalah mengatur kehidupan muslim dalam interaksinya dengan sesama makhluk lainnya termasuk bagian yang sangat vital yaitu ekonomi.

Dewasa ini bidang ekonomi sangat terbuka dalam memunculkan inovasi baru dalam membangun dan mengembangkan ekonomi masyarakat. Fikih muamalah sebagai akar dari ekonomi Islam harus bisa mengayomi muslim agar tidak terhambat dalam berinteraksi namun tidak keluar dari koridor Islam. Untuk itu fikih muamalah harus selalu siap dalam mengarahkan, memfilter, menerima, menolak dan memunculkan inovasi baru dalam membangun dan mengembangkan muamalah apalagi yang berhubungan dengan ekonomi.

Untuk menghadapi segala muamalah ekonomi yang belum ada ketentuan dalam Nașs dan belum dibahas dalam literatur klasik perlu istinbāt hukum secara logika dengan mempertimbangkan prinsip maqāṣid asy-syarī'ah. Maqāṣid asy-syarì'ah menjadi acuan dan patokan utama untuk menjaga keseimbangan sosial di masyarakat yang merupakan tujuan utama syariat Islam.

Berangkat dari sini, mengetahui seluk beluk maqāṣid asy-syarī'ah merupakan suatu keharusan bagi seorang muslim karena merupakan konsideran utama dalam mengevaluasi nilai manfaat dan mudarat dari kegiatan muamalah. Untuk itu dalam kesempatan ini penulis akan membahas secara ringkas tentang maqāṣid as-syarīah dan penerapannya dalam Ekonomi Islam.

\section{PEMBAHASAN}

\section{Pengertian Maqāṣid asy-Syarī‘ah dan Kaitannya Dengan Maṣlaḥah}

Maqāsid as-syarīah ditinjau dari sudut lughawi (bahasa) merupakan kata majemuk yang terdiri dari dua kata, yakni al-maqāṣid (الثريعة) dan as-syarīah (المقاصد). Akar kata maqāșid adalah qașada yaqșidu (قصد - يقصد) yang bermakna menyengaja, bermaksud kepada, maqāṣid merupakan bentuk jamak (plural) dari maqșid/maqșad (مقصد) yang berarti maksud, kesengajaan atau tujuan. ${ }^{1}$ Sedangkan syarī'ah (شريعة) dalam Bahasa Arab berarti jalan menuju sumber air. ${ }^{2}$ Jalan menuju sumber air ini dapat juga katakan sebagai jalan kearah sumber pokok kehidupan yaitu syariat

\footnotetext{
${ }^{1}$ Mahmud Yunus, Qāmūs 'Arabiy-Indūnīsiy (Jakarta: Hida Karya Agung, cet.8 1990), h. 343344 .

${ }^{2}$ Muhammad Ibn Mukrim Ibn Manẓūr al-Mișri, Lisān al-'Arab (Beirut: Dār aṣ-Ṣādir, tt), j. VIII, h. 175.
} 
Tuhan. ${ }^{3}$ Jadi maqāṣid as-syarīah mengandung makna tujuan dan rahasia yang diletakkan Syāri' (Allah) dari setiap hukum yang diturunkan oleh-Nya. ${ }^{4}$

Teori maqāṣid pada dasarnya sudah pernah diintrodusir oleh para cendekiawan muslim sebelum Imam Syāțibi (w. 790 H/1388 M), namun beliau kemudian mampu "mengkomunikasikan" teori tersebut dalam bentuk yang welldesigned sehingga ia dianggap salah satu peletak dasar secara komprehensif tentang ilmu maqāṣid as-syarīah hingga dijuluki dengan Bapak maqāṣid as-syarīah dengan bukunya yang terkenal Al-Muwāfaqāt. ${ }^{5}$

Mengkaji teori maqāșid asy-syarī’ah tidak dapat dipisahkan dari pembahasan mașlahah. Maqūṣid asy-syarī‘ah bermakna tujuan dan rahasia Allah meletakkan sebuah syariah, tujuan tersebut adalah mașlahah bagi seluruh umat. Mașlahah merupakan manifestasi dari maqāssid asy-syarī'ah (tujuan syariah) yaitu untuk mendatangkan mașlaḥah bagi hamba-Nya. Jadi dua istilah ini mempunyai hubungan dan keterkaitan yang sangat erat.

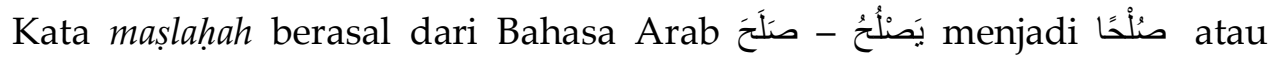
مَصََْحَلَ yang berarti sesuatu yang mendatangkan kebaikan dan manfaat. Kebalikannya atau lawannya adalah mafsadah (مفسدة) yang berarti kerusakan dan keburukan.

Secara etimologi, mașlaḥah sama dengan manfaat, baik dari segi lafal maupun makna. Mașlahah juga berarti manfaat atau suatu pekerjaan yang mengandung manfaat. Apabila dikatakan bahwa perdagangan itu suatu kemaslahatan dan menuntut ilmu itu suatu kemaslahatan, maka hal tersebut berarti bahwa perdagangan dan menuntut ilmu itu penyebab di perolehnya manfaat lahir dan batin.

Dalam perjalanan sejarah, lafal maṣlahah sudah digunakan dalam penalaran sejak zaman Sahabat, sebagai suatu prinsip bahkan istilah teknis namun belum dijelaskan secara tepat makna. Bahkan maknanya terus berkembang sampai zaman sekarang. ${ }^{6}$

Dalam kajian teori dasar hukum Islam (ușūl al-figh), Asmawi menyimpulkan mașlahah diidentifikasi dengan sebutan (atribut) yang bervariasi,

${ }^{3}$ Asafri Jaya Bakri, Maqashid Syari'ah Menurut Al-Syatibi (Jakarta: PT Raja Grafindo Persada, 1996), h. 61.

4 Ahmad Raisūni, Nazariyyah al-Maqāṣid 'Inda al-Imām asy-Syāṭibi (Riyadh: Ad-Dār al'Alamiyyah li al-Kuttāb al-Islāmiyyah, cet. 4, 1995), h. 18.

${ }^{5}$ Raisūni, Nazariyyah. h. 17.

${ }^{6} \mathrm{Al}$ Yasa' Abubakar, Metode Istislshiah, Pemanfaatan Ilmu Pengetahuan dalam Ushul Figh (Jakarta: Kencana, 2016), h.36. 
FITR AH Jurnal Kajian Ilmu-ilmu Keislaman

Vol. 03 No. 1 Juli 2017

yakni prinsip (principle, al-așl, al-qā'idah, al-mabda'), sumber atau dalil hukum (source, al-mașdar, ad-dalīl), doktrin (doctrine, ad-däbit), konsep (concept, al-fikrah), teori (theory, an-nazariyyah) dan metode (method, at-tarīqah). ${ }^{7}$

Secara terminologi, Para Ulama mendefinisikan mașlahah sebagai manfaat dan kebaikan yang dimaksudkan oleh Syāri' bagi hamba-Nya untuk menjaga agama, jiwa, akal, keturunan dan harta mereka. ${ }^{8}$

Mușțafā Zaid menegaskan, bagaimanapun istilah maṣlahah didefinisikan dan digunakan harus mengandung tiga hal, yaitu: pertama, mașlaḥah tersebut bukanlah hawa nafsu, atau upaya pemenuhan kepentingan individual, kedua, mașlahah mengandung aspek positif dan negatif, karena itu menolak kemudaratan sama dengan mendatangkan kemanfaatan, ketiga, semua mașlahah harus berhubungan baik langsung atau tidak langsung dengan lima aspek fundamental (al-kulliyah al-khamsah). ${ }^{9}$

Muhammad 'Abd al-'Ați Muhammad Ali menyebutkan bahwa mașlahah mempunyai tiga ciri utama: pertama, sumber dari maṣlahah itu adalah hidayah Allah, kedua, mașlahah mencakupi kehidupan dunia dan akhirat, ketiga, mașlahah tidak hanya terbatas pada kelezatan material. ${ }^{10}$

Dengan demikian, sebuah maṣlahah dan mafsadah yang masyrū' (legal), efeknya tidak bisa dipisahkan antara tujuan dunia ataupun tujuan akhirat namun mașlahah dan mafsadah di dunia akan selalu mempengaruhi kehidupan akhirat. Apabila hanya mementingkan kehidupan dunia dan mengenyampingkan akhirat, mașlahah itu cenderung mengikuti hawa nafsu dan harus ditinjau kembali.

\section{Urgensi Maqāṣid asy-Syarī'ah Dalam Ekonomi Islam}

Ekonomi Islam adalah bagian dari fikih muamalah yang mengkaji interaksi manusia yang berhubungan dengan kegiatan keuangan. Dalam perjalanannya tentu mengalami banyak perkembangan dan kemajuan. Hal-hal yang tidak terpikir pada zaman dahulu kala, menjadi kenyataan zaman sekarang. Maqāṣid asy-syarī‘ah yang melahirkan maṣlahah menjadi salah satu

\footnotetext{
${ }^{7}$ Asmawi, "Konseptualisasi Teori Maslahah", dalam Salam: Jurnal Filsafat dan Budaya Hukum (tanpa keterangan terbit), Permalink: https://www.academia.edu/9998895.

${ }^{8}$ Muhammad Sa'îd Ramaḍān al-Būṭi, Dawābit al-Maṣlahah fì asy-Syarī'ah al-Islāmiyyah (Beirut: Muassasah ar-Risālah, cet 6, 2001), h. 27.

${ }^{9}$ Muștafā Zaid, Al-Mașlaḥah Fī Tasyrī' al-Islāmi wa Najm ad-Dīn aț-ṭūfi, cet. 2 (Kairo: Dār al-Fikr al-'Arabi, 1964), h. 22

${ }^{10}$ Muhammad 'Abd al-'Ați Muhammad Ali, Al-Maqūṣid asy-syarī'ah wa Asaruhā Fì al-Fiqh alIslāmi (Kairo: Dār al-Ḥadī̇̀, 2007), h. 103.
} 
model pendekatan dalam ijtihad dan berkedudukan sangat vital dalam fikih muamalah. Maka para ahli teori hukum Islam menjadikan pengetahuan maṣlahah sebagai salah satu kriteria bagi mujtahid yang melakukan ijtihad. ${ }^{11}$

Ali Yasa' mengungkap bahwa pertimbangan maqāṣid asy-syarī‘ah dalam metode penalaran perlu dilakukan menurut asy-Syāṭibi karena Allah menurunkan syariat tidaklah secara sia-sia. Allah menurunkan hukum untuk kemaslahatan manusia didunia dan akhirat. Karena itu berupaya menemukan tujuan dan maslahat yang dikandung hukum agar tidak terjebak pada mementingkan formal semata, yang mungkin sekali akan kehilangan roh, yaitu kemaslahatan dan tujuan. ${ }^{12}$

Mașlahah merupakan esensi dari kebijakan-kebijakan syariah (siyāsah syar iyyah) termasuk juga kebijakan dalam perekonomian. Mașlahah ‘ammah (kemaslahatan umum) merupakan landasan muamalah, yaitu kemaslahatan yang dibingkai secara syar'iy, bukan semata-mata profit motive dan material rentability.

Kemunculan lembaga dan transaksi modern mendorong fikih muamalah untuk memandang interaksi ini dari sudut pandang yang baru juga. Kebutuhan akan fatwa dan ijtihad jamā'i semakin meningkat. Nașs yang ada, secara langsung belum cukup untuk menjawab problematika yang ada. Jika terabaikan maka kehidupan akan rusak. Disinilah butuh istinbāt hukum dengan menilik maqāsid asy-syarī'ah dan mașlahah secara tepat dan profesional. Jadi, untuk mengembangkan ekonomi Islam, para ekonom Muslim harus berpegang kepada mașlahah. Karena mașlahah adalah saripati dari syari'ah. Para ulama menyatakan "di mana ada mașlaḥah, maka di situ ada syariah Allah". ${ }^{13}$

Menurut Al Yasa' Abu Bakar, penetapan hukum dengan metode istislāhiyah (mașlahah) dapat digunakan dalam menyelesaikan dalam empat jenis masalah, yaitu: ${ }^{14}$

1. Mencari dan menemukan hukum atas suatu persoalan yang tidak mempunyai Nașs khusus (langsung) sebagai dalil. Ini adalah tujuan utama dari konsep maṣlahah.

\footnotetext{
${ }^{11}$ Waryani fajar Riyanto, “Pertingkatan Kebutuhan Dalam Maqasid Asy-Syari'ah, Dalam Jurnal Hukum Islam (JHI), Volume 8, Nomor 1, Juni 2010.

12 Al Yasa' Abubakar, Metode Istislahiah, Pemanfaatan Ilmu Pengetahuan dalam Ushul Figh (Jakarta: Kencana, 2016), h.11.

${ }^{13} \mathrm{http}: / / \mathrm{www}$.agustiantocentre.com/?p=424, diakses 20 September 2016.

${ }^{14} \mathrm{Al}$ Yasa' Abubakar, Metode Istislahiah,h. 58-60.
} 
FITR AH Jurnal Kajian Ilmu-ilmu Keislaman

Vol. 03 No. 1 Juli 2017

2. Sebagian dari penalaran ini, paling kurang dalam keadaan tertentu dapat juga digunakan untuk mennentukan hukum terhadap masalah baru yang sebetulnya telah mempunyai Nașs khusus, tetapi tidak secara sempurna.

3. Sampai batas tertentu, pola dan metode istișlăhiyah ini tidak diperlukan untuk menyelesaikan kasus-kasus baru, tetapi dapat juga digunakan untuk meneliti ulang, mengubah memperbaiki satau menyempurnakan peraturan lama.

4. Suatu masalah yang dahulu dianggap mempunyai Nașs khusus, tetapi ketika diteliti ulang terbukti penggunaannya tidak tepat, sehingga butuh metode istișlāhiyah.

Dari empat bentuk masalah diatas, sangat jelas bahwasanya masalah dalam ekonomi sangat butuh kepada metode penalaran ini. Kesimpulannya maqāssid asy-syarīah dan mașlahah dengan metode istișlāhiyah mempunyai kedudukan yang sangat penting dalam fikih Muamalah terutama dalam mu'āmalah māliyah (interaksi ekonomi). Dengan mașlahah, syariah Islam memiliki relevansi dengan konteks zamannya dan menjadi syariah selalu up to date menyapa segenap persoalan kehidupan manusia dengan cahaya ajarannya yang mencerahkan. Melalui mașlahah akan terealisasi kemakmuran dan kesejahteraan dan kemurnian pengabdian kepada Tuhan. Pengabaian mașlahah akan mendorong pada pengabaian kebutuhan manusia untuk melanjutkan hidup di dunia dan bahkan untuk mencapai kebahagian di akhirat.

\section{Cakupan Maqāṣid asy-Syarī’ah}

Maqāsid asy-syarīáh akan menjadi payung yang selalu memproteksi mașlahah. Maqāṣid asy-syarī'ah juga akan mengarahkan jalan untuk menuju mașlahah yang benar.

Dalam memproteksi mașlahah, maqāṣid asy-syarī‘ah menaungi lima unsur penting. Kelima unsur ini merupakan hal yang sangat fundamental dan mencakup secara menyeluruh kehidupan manusia sehingga sering disebut dengan al-kulliyah al-khamsah (5 aspek menyeluruh), sehingga kerusakan pada salah satu aspek saja akan menimbulkan implikasi negatif yang luar biasa. ${ }^{15}$ Sehingga maqāșid asy-syarī‘ah memberi perhatian, perlindungan dan proteksi (hifz) lebih terhadap lima unsur tersebut, yaitu menjaga agama atau keyakinan (hifžud-dīn), menjaga jiwa (hifẓun-nafs), menjaga keturunan (hifẓun-nasl), menjaga akal atau intelektual (hifzul-'aql) dan menjaga harta atau pproperti (hifzul-māl).

\footnotetext{
${ }^{15}$ Asy-Syātịibi, Al-Muwāāaqāt. j. I, h. 326.
} 
Imam asy-Syāțibi mempertegas bahwasanya proteksi (hifz) kelima aspek fundamental ini harus dilakukan dalam dua cara, yaitu: pertama; proteksi dengan cara pelaksanakan dan penjagaan dan perlindungan (positif/wujūd), kedua; dengan cara menghindari dan menghilangkan (negatif/'adam). Rukun Iman dan menunaikan ibadah seperti shalat, zakat, puasa dan sebagainya adalah proteksi dari segi wujūd dalam aspek ibadah. Menjaga kesehatan, mengkonsumsi makanan dan menyediakan tempat tinggal juga merupakan proteksi dari segi wujūd. Sementara mencegah kemungkaran, menghukum kriminal adalah contoh proteksi dari segi 'adam. ${ }^{16}$

Melihat pertimbangan beberapa penelitian dan pendapat Ulama kontemporer termasuk Imam Yusuf al-Qarāḍawi, Al Yasa' Abubakar menambahkan proteksi dan perlindungan kebutuhan keberlanjutan umat dan masyarakat (hifz al-ummah) dan pelestarian lingkungan hidup (hifz al-bīah) ke dalam al-kulliyah al-khamsah sehingga menjadi ad-darūriyyah as-sab'ah (tujuh unsur penting). ${ }^{17}$

Inilah yang menjadi patokan penting dalam menentukan mașlahah. Mașlahah yang akan diorganisir harus mendukung lima atau tujuh unsur ini dan tidak boleh berseberangan sedikitpun.

Tujuh unsur -apabila disetujui- yang diproteksi oleh maqāșid asy-syarì’ah, tingkat kepentingannya dibagi menjadi tiga tingkatan yang berurutan secara hierarkis, yaitu darūriyyāt (necessities/primer), hajiyyāt (requirements/sekunder), dan tahsiniyyat (beautification/tersier). ${ }^{18}$

Keperluan dan perlindungan menjadi tiga tingkatan ini, oleh asy-Syātịi dilakukan berdasarkan pengkajian dan penelitian atas ayat-ayat Alquran secara induktif dan komprehensif. Sehingga beliau beranggapan bahwa keberadaannya sudah mencapai tingkat qat'iy, maka memasukkannya kedalam penalaran dalam istinbāt hukum adalah hal yang sangat penting dan utama. ${ }^{19}$

Pertama; Maṣlahah darūriyyāt adalah sesuatu yang harus ada/dilaksanakan untuk mewujudkan kemaslahatan yang terkait dengan dimensi duniawi dan ukhrawi sekaligus. Apabila hal ini tidak ada, maka akan menyebabkan hilangnya hidup dan kehidupan seperti makan, minum, shalat,

${ }^{16}$ Asy-Syāṭibi, Al-Muwāafaqāt. j. I, h. 324-325.

${ }^{17}$ Ibid., h. 104.

${ }^{18}$ Abu Isḥāq asy-Syāțibi, Al-Muwāfaquāt fì Ușūl asy-Syarī‘ah (Beirut: Dār al-Ma'rifah, cet.3, 1997), j. I, h. 324.

${ }^{19} \mathrm{Al}$ Yasa' Abubakar, Metode Istislahiah. h. 12. 
FITR AH Jurnal Kajian Ilmu-ilmu Keislaman

Vol. 03 No. 1 Juli 2017

puasa, dan ibadah-ibadah wajib lainnya. Contohnya dalam muamalah adalah kewajiban melakukan akad dalam transaksi apapun. ${ }^{20}$

Kedua; Mașlahah hạjiyyāt adalah sesuatu yang sebaiknya ada sehingga dalam melaksanakannya leluasa dan terhindar dari kesulitan. Kalau sesuatu ini tidak ada, maka ia tidak akan menimbulkan kerusakan atau kematian namun akan berimplikasi adanya kesulitan dan kesempitan yang besar. Contoh yang diberikan oleh Imam Syāṭibi dalam hal muamalat pada bagian ini adalah dilegalkan beberapa transaksi bisnis dalam fikih muamalah, antara lain qirāz atau muḍārabah, musāqah dan salam..$^{21}$

Ketiga; Mașlahah tahsininiyyāt adalah sesuatu yang tidak mencapai taraf dua kategori di atas. Hal-hal yang masuk dalam kategori tahsīniyyāt jika dilakukan akan mendatangkan kesempurnaan dalam suatu aktivitas yang dilakukan, dan bila ditinggalkan maka tidak akan menimbulkan kesulitan.

Ketiga pembagian tersebut harus dipahami secara berurutan, apabila berseberangan maka mașlahah darūriyyāt (necessities/primer) harus didahului daripada maṣlahah hajizyāat (requirements/sekunder), setelah maṣlahah darūriyyāt dan maṣlahah hajiyyāt terpenuhi baru memenuhi maṣlaḥah tahsinniyyat (beautification/tersier).

\section{Dawābiṭ (Kriteria) Mașlahah dalam Fikih Muamalah}

Mașlaḥah bukanlah dalil independen dari pada adillah syar'iyyah (dalildalil syar'i) seperti Alquran, Sunah, Ijmak dan Kias sehingga bisa berdiri sendiri untuk meng-istinbāt sebuah hukum. Namun mașlahah adalah penunjang dan kesimpulan dari kepingan-kepingan sumber yang mendukung kemaslahatan hamba dunia dan akhirat. ${ }^{22}$

Dalam periode terakhir, muncul pendapat yang mendahulukan mașlahah dari pada Nașs Alquran dan Hadis. Sangat jelas pendapat ini harus ditolak dan sama sekali tidak sesuai dengan ajaran syariah. Nașs yang ada pasti sudah sangat sejalan dengan maṣlahah, karena itulah tujuan syāri'. Jika berpegang pada mașlahah mungkin akan ada Naśs yang dikesampingkan, tapi jika berpegang pada Nașs pasti akan ada mașlahah disana.

Maṣlahah adalah salah satu metode istinbāt hukum yang menggunakan logika. Logika manusia sangat terbatas dan mudah terpengaruh dengan hal

\footnotetext{
${ }^{20}$ Ahmad Qorib, Ushul Figh 2 (Jakarta: Nimas Multima, cet. 2, 1997), h. 175.

${ }^{21}$ Asy-Syātịi, Al-Muwāäaqāt. j. I, h. 326.

22 Al-Būṭi, Dawāoiț. h. 107.
} 
yang tidak diinginkan, untuk itu, dalam mengambil istinbāt hukum dengan mașlahah ada kriteria yang harus dipenuhi. Kriteria ini sebagai dasar dan tameng seorang mujtahid dalam menentukan mașlahah. Diantara kriteria tersebut adalah: ${ }^{23}$

1) Mașlahah yang dimaksud harus tetap, atau sasaran yang hendak diwujudkan pasti bukan hanya semata dugaan atau hendaknya dugaan kuat yang mendekati kepastian.

2) Mașlahah tersebut harus jelas. Kejelasan yang dimaksud adalah sesuatu yang tidak samar-samar dan tidak serupa dengan yang lain, sehingga Para Fukaha juga akan jauh dari perbedaan pendapat atasnya. Misalnya syariat pernikahan untuk menjaga keturunan, ini adalah tujuan yang jelas.

3) Mașlahah tersebut harus munḍabit, yaitu maksud yang dikehendaki mempunyai ukuran dan batasan yang pasti.

4) Mașlahah tersebut muḍttarid, yaitu tujuannya mengikat tidak berubah dengan perubahan masa dan tempat.

Syeikh Ramaḍān al-Būṭi (Ulama kontemporer dari Syiria) menyebutkan beberapa kriteria maṣlahah lainnya sehingga bisa dikatakan legal. ${ }^{24}$

1) Maṣlahah tersebut merupakan bagian dari maqūṣid asy-syāri' yang terdiri dari memproteksi pada lima hal yaitu menjaga agama (hifzud-dinn), menjaga jiwa (hifzun-nafs), menjaga keturunan (hifžnn-nasl), menjaga akal (hifz̨ul-'aql) dan menjaga harta (hifzul-māl).

2) Maṣlahah tersebut tidak boleh bertentangan dengan ketentuan Nașs atau ketentuan ijmak dan Kias.

3) Mașlahah tersebut tidak mengabaikan mașlahah yang lebih penting atau setara dengannya.

Inilah beberapa kriteria yang harus dipenuhi dan dipahami oleh seseorang yang ini berkecimpung dalam mașlahah. Dengan memperhatikan kriteria ini diharapkan penentuan mașlahah akan jauh dari hawa nafsu.

\section{Ragam Kemaslahatan}

Mașlahah sangat erat kaitannya dengan kehidupan, sehingga kemaslahatan sangat beragam tergantung memandang dari sudut yang mana. Kekuatan mașlahah tersebut juga berbeda antara satu dengan yang lainnya dan tidak semua mașlahah bisa dipergunakan.

${ }^{23}$ Ahmad Qarib, Ushul. h. 175.

${ }^{24}$ Al-Būṭi, Dawāäbiț. h. 105. 
FITR AH Jurnal Kajian Ilmu-ilmu Keislaman

Vol. 03 No. 1 Juli 2017

Ragam mașlahah yang sangat terkenal dan sudah kita singgung sebelumnya adalah ragam mașlahah yang dilihat dari sudut pandang kekuatan dan kepentingan yang dibagi menjadi tiga tingkatan yang berurutan secara hierarkis, yaitu darūriyyāt (necessities/primer), hajiyyāt (requirements/sekunder), dan tahsiniyyat (beautification/tersier).

Selain dari klasifikasi diatas, Para Ulama memetakan mașlahah dari beberapa sudut pandang. Diantaranya mașlahah jika dilihat dari berubah atau tidaknya mașlahah dibagi dalam dua bentuk, yaitu :

1) Mașlahah a $\dot{s}-\dot{s} \bar{a} b i t a h$, yaitu kemaslahatan yang bersifat tetap, tidak berubah sampai akhir zaman. Misalnya, berbagai mașlahah dalam kewajiban ibadah.

2) Mașlahah al-mutagayyirah, yaitu kemaslahatan yang berubah-ubah sesuai dengan perubahan tempat, waktu dan subjek hukum. Kemaslahatan seperti ini berkaitan dengan permasalahan muamalah dan adat kebiasaan, seperti dalam masalah makanan yang berbeda-beda antara satu daerah dengan daerah lainnya.

Diantara dua mașlahah ini maka mașlahah aś-sābitah lebih kuat daripada mașlahah al-mutagayyirah dan lebih diutamakan ketika pada saat berseberangan.

Jika dilihat dari segi keberadaan mașlahah menurut legalitas syara' dibagi menjadi tiga, yaitu:

1) Mașlahah al-mu'tabarah, yaitu kemaslahatan yang didukung oleh syara' maksudnya mașlahah tersebut ada dalil khusus yang menjadi dasar bentuk dan jenisnya.

2) Mașlaḥah al-mulgāh, kemaslahatan yang ditolak syara', karena bertentangan dengan ketentuan syariah.

3) Mașlahah mursalah yaitu kemaslahatan yang keberadaannya tidak didukung syara' dan tidak pula dibatalkan/ditolak syara' melalui dalil-dalil yang rinci. Artinya maṣlahah yang tidak diperintahkan di dalam Alquran dan Hadis, akan tetapi tidak bertentangan terhadap keduanya. Misalnya, pendirian bank syariah sebagai lembaga yang menghubungkan antara pemilik modal dan pekerja. Dalam Alquran atau Hadis tidak ada perintah untuk mendirikan lembaga perbankan syariah, akan tetapi keberadaannya tidak dilarangan oleh Alquran atau Hadis. Disamping itu, keberadaan lembaga perbankan membawa atau mendatangkan manfaat bagi masyarakat dan manfaat tersebut tidak bertentangan dengan nash seperti prinsip bagi hasil 
(akad mud̄ārabah), maka di antara kedua belah pihak akan mendapatkan manfaat dari hasil kerja sama tersebut.

Diantara tiga ragam mașlahah ini, tidak diragukan lagi bahwa mașlahah yang paling kuat adalah mașlahah al-mu'tabarah. Sementara mașlahah al-mulgāh sama sekali tidak bisa digunakan. Sementara mașlahah mursalah menjadi dalil kuat dan menjadi rujukan dalam menghadapi perkembangan zaman saat ini.

Dari segi kandungan dan cakupan, mașlahah dibagi menjadi:

1. Mașlahah al-'ammah, yaitu kemaslahatan umum yang menyangkut kepentingan orang banyak. Kemaslahatan umum ini tidak berarti untuk semua kepentingan orang, tetapi bisa berbentuk kepentingan mayoritas ummat/kelompok.

2. Mașlahah al-khașșah, yakni kemaslahatan yang kembali kepada pribadi atau kembali kepada kepentingan sebagian kecil masyarakat, seperti kermaslahatan yang berkaitan dengan pemutusan hubungan perkawinan seseorang yang dinyatakan hilang (mafqūd).

Diantara dua mașlahah ini tentu mașlahah al-'ammah lebih diutamakan daripada maṣlahah al-khașșah.

\section{Pilihan Prioritas dalam Ragam Kemaslahatan}

Pada posisi tertentu muncul beberapa mașlahah yang saling bertolak belakang. Pada saat itu seseorang harus bisa menentukan mașlahah dominan dan men-tarjih-kan sesuai dengan kriteria, standar dan tingkatan dalam pelbagai ragam mașlahah yang ada. Sederhananya adalah apabila kontradiksi berlaku di antara maṣlahah rājịhah (kuat) dengan mașlahah marjūhah (lemah) maka hendaklah diutamakan mașlahah rājihah.

Diantara beberapa keragaman mașlahah, sudah kita tentukan mana mașlahah yang paling dominan (räjịhah) pada saat kita bahas ragam kemaslahatan.

Selanjutnya kita akan menyempurnakan penyelesaian dalam menentukan maṣlahah rājịhah sebagaimana berikut: ${ }^{25}$

1) Utamakan maṣlahah mutayaqqanah (qațiyyah) daripada maṣlahah mauhūmah (zanniyyah).

Mașlahah qațiyyah adalah mașlahah yang sudah pasti dan didukung oleh dalil-dalil yang qat’iy. Sementara mașlahah zanniyyah adalah

25 Rizdwan Ahmad, "Metode Pentarjihan Mașlaḥah dan Mafsadah Dalam Hukum Islam Semasa" dalam Shariah Journal, Vol. 16, No. 1 (2008). 
FITR AH Jurnal Kajian Ilmu-ilmu Keislaman

Vol. 03 No. 1 Juli 2017

kebalikannya. Apabila terjadi kontradiksi antara dua mașlahah ini maka yang diutamakan adalah mașlahah qațiyyah. Misalnya menyerahkan zakat fitrah dalam bentuk makanan pokok kepada mustahiq lebih diutamakan dari pada menyerahkan dalam bentuk uang disebabkan oleh dalil yang lebih kuat dan qat'iy.

Keutamaan Mașlaḥah qațiyyah daripada mașlahah zanniyyah ini telah melahirkan banyak kaedah-kaedah figh. Di antaranya ialah:

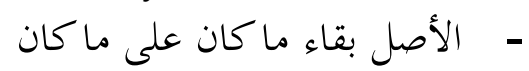

Artinya: "Asal itu kekal seperti sedia kala".

$$
\text { - }
$$

Artinya: "Sesuatu yang keberadaannya ditetapkan dengan yakin maka tidak dapat dihilangkan melainkan dengan yakin juga"

$$
\text { - ل ال عبرة بالظن خطؤ - }
$$

Artinya: “Tidak diambil sesuatu yang kesalahannya diputuskan dengan cara $z a n n^{\prime \prime}$.

Artinya: "Tidak diambil perkiraan dengan cara wahm ${ }^{26 "}$

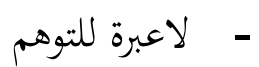

2) Utamakan maṣlaḥah yang bersifat asasi ataupun fundamental Daripada maṣlahah yang hanya bersifat teknis (syakliyyah)

Mașlahah yang bersifat asasi di sini ialah mașlaḥah hakiki yang hendak dicapai sedangkan mașlahah tersebut tidak tampak atau terlihat secara zahir. sementara mașlahah yang bersifat teknis itu bersifat zahir namun tidak dikehendaki terjadi pada hakikatnya. Misalnya orang tua yang tidak memenuhi semua keinginan anaknya karena memikirkan masa depan mereka, meskipun terlihat ada mafsadah pada saat itu namun mașlahah dimasa yang akan datang.

3) Utamakan mașlahah yang bersifat kekal dan berterusan Daripada mașlahah yang hanya bersifat sementara.

Mașlaḥah yang bersifat kekal adalah mașlaḥah yang manfaatnya kekal ataupun kewujudannya terus menerus. Sementara mașlaḥah sementara yaitu manfaatnya berlaku hanya sekali, terbatas kepada waktu tertentu ataupun tertumpu kepada ibadah khusus saja. Misalnya sedekah yang diberikan kepada individu tertentu. Manfaatnya hanya berlaku ke atas individu itu saja dan akan terputus manfaatnya apabila digunakan atau dimanfaatkan.

${ }^{26}$ Wahn adalah keragu-raguan mencapai $75 \%$ dan hanya meyakini $25 \%$ saja. 
Sesungguhnya Islam lebih mengutamakan amalan yang bersifat berterusan dibanding hanya bersifat terbatas dan sementara.

Berdasarkan diatas maka amalan yang mașlahah-nya wujud secara berterusan lebih diutamakan. Contohnya seseorang hartawan yang mampu mengerjakan haji sunat pada setiap tahun sedangkan banyak sekolahsekolah agama ataupun pelajar-pelajar agama miskin yang memerlukan bantuan dari mereka. Maka hendaklah dia mengutamakan tindakan membantu pembiayaan sekolah dan pelajar tersebut dengan mewakafkan biaya haji sunat yang dimiliki untuk membantu dan meringankan beban mereka.

4) Diutamakan maṣlạ̣ah kubrā (besar) Dari pada maslahah sugra (kecil)

Di antara mașlaḥah darūriyyah, häjiyyah dan taḥsiniyyah ada yang dikategorikan ke dalam ammah dan khașsah. Apabila berlaku kontradiksi di antara kedua maṣlahah yang mempunyai jenis yang sama dalam kedudukan yang sama maka hendaklah diutamakan mașlahah kubrā ataupun maṣlahah yang lebih penting daripada mașlahah sugrā ataupun yang kurang penting.

Berikut ini salah satu standar untuk mengetahui mașlahah penting atau kurang penting:

(a) Utamakan mașlahah yang apabila diabaikan akan membawa akibat lebih buruk dari mașlahah yang apabila diabaikan akan membawa akibat kurang buruk. Contohnya, apabila kas negara tidak mampu menanggung biaya dua program yaitu pembangunan negara yang melibatkan proyek-proyek mewah dan menaikkan taraf golongan miskin di seluruh pelosok negara, maka hendaklah diutamakan program atas golongan miskin. Ini kerana jika golongan miskin diabaikan, maka kerusakan lebih besar dibandingkan pengabaian atas proyek mewah.

(b) Utamakan maslahah yang dititikberatkan secara khusus oleh Syara' daripada mașlahah lainnya. Apabila seseorang itu tak mampu menghilangkan najis sedangkan jika ingin menghilangkannya waktu shalat akan luput maka hendaklah dia shalat demi menjaga waktu, Karena shalat pada waktunya lebih utama.

(c) Utamakan mașlahah yang lebih dari sudut kepentingan diri dan hubungan kaum kerabat dibanding mașlahah yang lebih jauh darinya. Apabila seorang itu tidak mampu menanggung nafkah dirinya jika dia 
FITR AH Jurnal Kajian Ilmu-ilmu Keislaman

Vol. 03 No. 1 Juli 2017

menanggung nafkah kedua ibu bapanya ataupun anak-anaknya dan isterinya, maka hendaklah diutamakan nafkah ke atas dirinya.

(d) Utamakan mașlahah yang dilakukan oleh Rasulullah secara berterusan berbanding dilakukan-Nya sesekali saja. Misalnya salat qasar untuk musafir diutamakan dari solat sempurna, karena Rasulullah tidak pernah melakukan salat empat rakaat ketika dalam perjalanan.

(e) Diutamakan mașlah̆h yang disepakati oleh para Ulama daripada mașlahah yang masih diperdebatkan di kalangan mereka.

Aț-Ṭúfi juga menjelaskan cara untuk menghukum sebuah mașlahah, yaitu:27

1. Jika suatu perbuatan mengandung mașlahah semata, maka silahkan dikerjakan.

2. Jika suatu perbuatan mengandung mafsadah semata, maka harus ditinggalkan.

3. Jika suatu perbuatan mengandung mașlahah di satu sisi dan mafsadah di sisi lain dengan kadar yang seimbang dalam pandangan kita, maka:

a. Mengajukan kepada seorang yang dianggap ahli untuk menilai yang lebih tepat untuk dikerjakan.

b. Memilih salah satunya atas pertimbangan sendiri. Contoh: jika tidak ada penutup aurat kecuali selembar kain yang hanya cukup untuk menutupi salah satu dari dua kemaluan, kita bisa memilih, apakah akan menutupi qubul ataukah dubur?

4. Jika suatu perbuatan memiliki kadar maṣlahah yang lebih besar, maka silahkan dikerjakan. Sebaliknya, jika kadar mafsadahnya yang lebih besar, maka perbuatan tersebut harus ditinggalkan. Sebab beramal terhadap sesuatu yang lebih kuat, merupakan tuntutan syara'. Akurasi metode ini dapat dibuktikan dengan mengkonfirmasikannya pada contoh-contoh yang dikemukakan para ulama ketika membagi mașlahah sebagaimana pembagian di atas. Untuk mașlahah d̦arūriyyah dan mu'tabarah, meski mengandung mafsadah seperti hukuman pelaku pidana, hukum cambuk, hukum potong tangan dan lain-lain, tetap dilaksanakan karena nilai mașlahah-nya lebih besar.

Semua keragaman mașlahah apabila bertolak belakang juga harus merujuk kepada kulliyyah al-khamsah yaitu memproteksi pada lima hal yaitu menjaga

27 Iffah Muzammil, "Maṣlaḥah Sebagai Sumber Hukum Islam Menurut Najm al-Dīn al-Ṭūfy, dalam Al-Qānūn, Vol. 13, No. 1, Juni 2010. 
agama (hifẓud-dinn), menjaga jiwa (hifẓun-nafs), menjaga keturunan (ḥifzzun-nasl), menjaga akal (hifžl-'aql) dan menjaga harta (hifẓul-māl). Kelima elemen ini diutamakan mașlahah-nya sesuai urutannya. Misalnya seseorang diancam akan dibunuh apabila tidak menyerahkan hartanya, maka dia memilih untuk menyerahkan hartanya, karena menjaga jiwa lebih utama dari menjaga harta.

\section{Penerapan Maqāṣid asy-Syar̄̄ah Dalam Ekonomi Islam}

Kegiatan ekonomi tak bisa terlepas dari kegiatan kepemilikan dan harta. Seluruh Ulama telah sepakat bahwasanya memproteksi harta adalah salah satu bagian dari maqāṣid asy-syarì‘ah dan bagian dari mașlahah yang lima (atau tujuh) yang harus dilindungi. Dalam Islam harta juga mempunyai tempat penting sebagai sarana kebahagian dunia dan akhirat. ${ }^{28}$

Aplikasi maqāṣid asy-syarī’ah dan mașlahah sudah terjadi sejak dulu. Dalam sejarah, Khalifah Abu Bakr as-Ṣiddīq memutuskan untuk menyerang Muslimin yang tidak mau menunaikan zakat, karena selain ibadah zakat juga merupakan pemasukan utama negara untuk mensejahterakan ekonomi rakyat. Khalifah Umar bin Khattab pernah melarang kaumnya untuk makan daging dua hari berturut-turut karena krisis. Beliau juga pernah menjual secara paksa barang timbunan dengan harga standar dan juga pernah mematok harga untuk menghindari monopoli dan bahaya untuk rakyat. Semua itu berangkat dari mașlahah. ${ }^{29}$

Dalam kegiatan ekonomi mikro, Islam sebagai rahmah li al-álamìn mengatur seluk beluk konsumsi (istihlāk), distribusi (tauzī') dan produksi (intāj). Semua pengaturan tersebut mengarah pada mașlahah untuk menjaga dan menjauhi kegiatan pengabaian dan menyia-nyiakan (id̄áah) hak milik, seperti perintah potong tangan untuk pencuri, larangan mubazir dan masih banyak lagi.

Dewasa ini, aplikasi maqāṣid asy-syarī'ah dalam menjawab kemajuan sains dan teknologi modern sangatlah banyak. Diantaranya dilegalkannya lembaga dan transaksi baru sebagai jawaban dari panggilan kebutuhan masyarakat. Diantaranya mendirikan perbankan, asuransi, sukuk, mortgage dan multifinance, capital market, mutual fund, Multi Level Marketing (MLM), tatacara perdagangan melalui e-commerce, sistem pembayaran dan pinjaman dengan kartu kredit, sms

28 Yūsuf al-Qaraḍāwi, Maqāṣid asy-syarī'ah al-Muta'alliqah bi al-Māl (Kairo: Dār asy-Syurūq, 2010), h. 10.

${ }^{29}$ Muhammad Syauqi al-Fanjari, al-Mażhab al-Iqtișādiy fì al-Islām (Kairo: al-Hai'ah al-Mișriyyah al-'Ammah li al-Kitāb, 2010), h. 227-228. 
FITR AH Jurnal Kajian Ilmu-ilmu Keislaman

Vol. 03 No. 1 Juli 2017

banking, ekspor impor dengan media L/C, sampai kepada instrumen pengendalian moneter, exchange rate, wakaf saham dan lain-lain.

Mașlahah juga tidak akan pernah lepas dari fatwa-fatwa kontemporer. Di Indonesia, DSN MUI juga menerapkan maqāșid asy-syarī'ah dalam banyak fatwa yang dikeluarkannya, diantaranya fatwa kebolehan jual-beli emas secara tidak tunai, yang pada dasarnya emas dikategorikan dalam aset yang mengandung riba. $^{30}$

Semua hal tersebut dilihat terdapat mașlahah yang sangat besar bagi umat untuk mengembangkan ekonomi. Selama tidak bertentangan dengan syariah, inovasi-inovasi baru tersebut sangatlah penting dan dibutuhkan untuk diwujudkan.

\section{PENUTUP}

Mașlahah sangat penting dalam ekonomi Islam dan menduduki tempat yang sangat vital dalam menentukan hukum. Zaman yang terus berkembang dengan berbagai inovasi kehidupan, muncul kejadian-kejadian baru yang belum tersentuh fikih klasik. Disinilah mașlahah berperan penting. Meskipun demikian, mașlahah bukanlah satu-satunya dalil atau dalil independen dalam menentukan hukum. Mașlaḥah harus dikuatkan dengan dalil-dalil lain meski secara tidak langsung sehingga mașlahah itu benar-benar tepat dan profesional.

Dikarenakan mașlahah lahir dari sebuah penalaran dan logika manusia, maka butuh kriteria-kriteria dan standar yang harus dipahami sebelum memutuskan sebuah mașlaḥh. Kriteria dan standar tersebut akan mengarahkan penentuan mașlahah yang bebas dari hawa nafsu dan kepentingan dunia semata. Wallāh a'lā wa a'lam bi aș-ṣawāb.

${ }^{30}$ Lihat detailnya: Oni Sahroni dan Adiwarman A. Karim, Maqashid Bisnis \& Keuangan Islam (Jakarta: Rajawali Pers, 2016), h. 141-146. 


\section{DAFTAR PUSTAKA}

Ali, Muhammad 'Abd al-'Ați Muhammad. Al-Maqāșid asy-syarī'ah wa Asiaruhā F̄̄ al-Figh al-Islāmi. Kairo: Dār al-Ḥad̄ìs, 2007.

Abubakar, Al Yasa'. Metode Istislahiah, Pemanfaatan Ilmu Pengetahuan Dalam Ushul Figh. Jakarta: Kencana, 2016.

Al-Būṭi, Muhammad Sa'īd Ramaḍān. Dawābit al-Maṣlahah fì asy-Syarī'ah alIslāmiyyah. Beirut: Muassasah ar-Risālah, cet 6, 2001.

Al-Fanjari, Muhammad Syauqi. Al-Mażhab al-Iqtișādiy fì al-Islām. Kairo: al-Hai'ah al-Miṣriyyah al-'Ammah li al-Kitāb, 2010.

Al-Miṣri, Muhammad Ibn Mukrim Ibn Manẓūr. Lisān al-'Arab. Beirut: Dār aṣȘādir, tt.

Asmawi, "Konseptualisasi Teori Maslahah", dalam Salam: Jurnal Filsafat dan Budaya Hukum (tanpa keterangan terbit), Permalink: https://www.academia.edu/9998895.

Asy-Syātịibi, Abu Isḥāq. Al-Muwāafaqāt fì Ușūl asy-Syarī‘ah. Beirut: Dār al-Ma'rifah, cet.3, 1997.

Al-Qaraḍāwi, Yūsuf. Maqāșid asy-syarī'ah al-Muta'alliqah bi al-Māl. Kairo: Dār asySyurūq, 2010.

Bakri, Asafri Jaya. Maqashid Syari'ah Menurut Al-Syatibi. Jakarta: PT Raja Grafindo Persada, 1996.

Muzammil, Iffah. "Maṣlaḥah Sebagai Sumber Hukum Islam Menurut Najm alDīn al-Ṭūfy, dalam Al-Qānūn, Vol. 13, No. 1, Juni 2010.

Qorib, Ahmad. Ushul Figh 2. Jakarta: Nimas Multima, cet. 2, 1997.

Rizdwan Ahmad, "Metode Pentarjihan Mașlahah dan Mafsadah Dalam Hukum Islam Semasa" dalam Shariah Journal, Vol. 16, No. 1 (2008).

Riyanto, Waryani fajar, "Pertingkatan Kebutuhan Dalam Maqasid Asy-Syari'ah, Dalam Jurnal Hukum Islam (JHI), Volume 8, Nomor 1, Juni 2010.

Raisūni, Ahmad. Nazariyyah al-Maqāṣid 'Inda al-Imām asy-Syātibi. Riyadh: Ad-Dār al-'Alamiyyah li al-Kuttāb al-Islāmiyyah, cet. 4, 1995.

Sahroni, Oni dan Adiwarman A. Karim. Maqashid Bisnis E Keuangan Islam. Jakarta: Rajawali Pers, 2016. 
FITR AH Jurnal Kajian Ilmu-ilmu Keislaman

Vol. 03 No. 1 Juli 2017

Yunus, Mahmud. Qāmūs 'Arabiy-Indūnīsiy. Jakarta: Hida Karya Agung, cet.8 1990.

Zaid, Muṣțafā. Al-Maṣlaḥhh F̄̄ Tasyrī’ al-Islāmi wa Najm ad-Dīn aț-ṭūfi. cet. 2, Kairo: Dār al-Fikr al-'Arabi, 1964.

http://www.agustiantocentre.com/?p=424. 